Copyright (C) 2021 University of Bucharest Printed in Romania. All rights reserved

ISSN print: $1224-5984$

ISSN online: $2248-3942$
Received for publication, November, 18, 2021

Accepted, December, 12, 2021

Original paper

\title{
Yield results obtained in maize crop following the foliar fertilization with new biostimulators based on keratin and collagen hydrolysates of animal origin
}

\author{
MARIUS BECHERIȚU ${ }^{1}$, ROXANA HOROIAȘ ${ }^{1}$, CRISTIAN CIOINEAG ${ }^{1}$, \\ PAUL BOROVINĂ $\breve{1}^{1}$, CARMEN GAIDĂU ${ }^{2}$, MIHAELA NICULESCU ${ }^{2}$ \\ ${ }^{1}$ Probstdorfer Saatzucht Romania SRL, 20 Siriului Street, 014354, District 1, Bucharest, Romania \\ ${ }^{2}$ The Research and Development National Institute for Textiles and Leather - Division Leather and \\ Footwear Research Institute, Leather Research Department, 93 Ion Minulescu Street, 031215, \\ Bucharest, Romania
}

\begin{abstract}
The aim of the paper is to show the reaction of maize crop to the foliar application of new biofertilizers, obtained from the residues left after the wool tanning process and which are based on protein hydrolysates of keratin and collagen. The tests have been performed in microplots (10 sqm) and macroplots (1000 sqm), in three repetitions, in southern Romania. All data obtained as a result of the 2020 autumn harvest have been centralized in tables and statistically processed, in order to establish the influence of each product, compared to the control. The bifactorial analyses show that, in climatic stress conditions (prolonged drought - Calarasi), very significant increases in yield have been obtained with $\mathrm{K} 4(2.5$ and $5.0 \mathrm{l} / \mathrm{ha}), \mathrm{K} 5(5.0 \mathrm{l} / \mathrm{ha})$ and $\mathrm{C}(5.0 \mathrm{l} / \mathrm{ha})$, with increases between 700 and $1300 \mathrm{~kg} / \mathrm{ha}$, ie up to $+24 \%$. In macroplots, subject to a moderate drought (Teleorman), product C $(5.0 \mathrm{l} / \mathrm{ha})$ brought a yield increase of $1537 \mathrm{~kg} / \mathrm{ha}(+26 \%)$, noting that in this location almost all tested biostimulators offer very significant yield growth (except KC). Based on the 2020 yields, it was possible to identify which the foliar biostimulators that will continue to be tested in 2021.
\end{abstract}

Keywords maize, foliar fertilization, biostimulator, keratin hydrolysate, yield

To cite this article: BECHERIȚU M, HOROIAȘ R, CIOINEAG C, BOROVINĂ P, GAIDĂU C, NICULESCU M. Yield results obtained in maize crop following the foliar fertilization with new biostimulators based on keratin and collagen hydrolysates of animal origin. Rom Biotechnol Lett. 2021; 26(6): 3129-3136. DOI: 10.25083/rbl/26.6/3129-3136.

*Corresponding author: ROXANA HOROIAȘ, Probstdorfer Saatzucht Romania SRL, 20 Siriului Street, 014354, District 1, Bucharest, Romania Tel: +40746224204

E-mail: roxana.horoias@probstdorfer.ro 


\section{Introduction}

It has been repeatedly proven that foliar fertilization can compensate an insufficient nutrition from the soil, as long as the foliar surface is well developed (LING \& SILBERBUSH, 2002 [1]; FERNANDEZ \& EICHERT, 2009 [2]; BRANKOV et al, 2020 [3]), and the amount of fertilizer is well correlated with the needs of the plants (GIRMA et al, 2007 [4]; ANDRIC et al, 2016 [5]; BERNHARD, 2016 [6]; ADAMEC et al, 2020 [7]).

In addition, for foliar fertilization, products of natural origin can be used with much higher efficiency (FERNANDEZ et al, 2013 [8]), to replace some of the synthetic nutrients (MONDA et al, 2018 [9]), with longterm economic and ecological effects (FRANCIS et al, 2016 [10]). Biostimulators are that kind of products, having the role of promoting the growth, the development and the productivity of plants (KOCIRA et al, 2020 [11]).

In maize crop, it has been shown that biostimulators improve the absorption of nutrients by plants, especially by increasing the leaf (DA SILVA, 2018 [12]) and roots (TADROS et al, 2019 [13]) biomass, but also by accelerating the transport or translocation of nutrients and the enzymatic activity involved in their assimilation (BULGARI et al, 2019 [14]). At the same time, the role of biostimulators is to increase the tolerance level of plants against abiotic stresses (HU et al, 2008 [15]; BROWN \& SAA, 2015 [16]; TREVISAN et al, 2019 [17]; VAN OOSTEN et al, 2017 [18]), which can be quantified by the way plants evolve during vegetative cycles (HOROIAS et al, 2021 [19]), and then by quantitative and qualitative evaluation of the obtained yields (JAKAB-GABOR et al, $2017[20])$.

The use of animal waste in agriculture is a process increasingly tested in recent years, used in different crops (ERTANI et al, 2013 [21]; BECHERITU et al, 2020 [22]). Obtaining efficient biostimulators with minimal costs, from the residues left as a result of wool processing (BEN et al, 2020 [23]; GAIDAU et al, 2021 [24]), would be an important achievement for producers, but also for farmers (YAKHIN et al, 2017 [25]).

\section{Materials and Methods}

\section{Choosing the biological material - maize hybrid}

As a first step, the biological material that is going to be used in order to test the new biostimulators on the maize crop has been chosen. Taking into consideration the research area (southern Romania) pedoclimatic conditions, the Olt hybrid (a Romanian one, included in the 430 FAO group) has been considered to be the most suitable. The selection criterion was also based on continuity, knowing that this hybrid it will be available for the next two years of research.

\section{Establishing the locations for field research}

Choosing locations for the testing plots has been based, mostly, on the rainfall regime from the beginning of 2020, respectively January-April, an extremely useful information in order to know what is the water resource from the soil. All data were collected in Table 1, subsequently supplemented with data up to the end of August 2020, thus having the precipitation balance for the entire maize growing period.

Table 1. Precipitation recorder in the two locations where the biostimulators field tests were conducted - micro- and macroplots

\begin{tabular}{|c|c|c|c|}
\hline \multirow[b]{2}{*}{ Crt. } & \multirow[b]{2}{*}{ Month } & \multicolumn{2}{|c|}{ Precipitation $(\mathrm{mm})$} \\
\hline & & $\begin{array}{c}\text { Modelu } \\
\text { (Calarasi) - } \\
\text { microplots }\end{array}$ & $\begin{array}{c}\text { Calomfiresti } \\
\text { (Teleorman) - } \\
\text { macroplots }\end{array}$ \\
\hline 1. & January & 2 & 6 \\
\hline 2. & February & 31 & 68 \\
\hline 3. & March & 16 & 74 \\
\hline 4. & April & 11 & 20 \\
\hline 5. & Total & 60 & 168 \\
\hline 6. & May & 75 & 61 \\
\hline 7. & June & 105 & 105 \\
\hline 8. & July & 18 & 17 \\
\hline 9. & August & 3 & 22 \\
\hline 10. & TOTAL & 261 & 373 \\
\hline
\end{tabular}

The elements that determined us to carry out field tests in these two locations were the different distribution of monthly precipitation, as well as the fact that, until the time of sowing (April 20, 2020), in Teleorman county the soil had stored a volume of water $108 \mathrm{~mm}$ higher than in Calarasi county, on the background of a more balanced distribution. For the rest of the period (May-August 2020), the rainfall regime of the two locations was similar.

Regarding the pedological conditions of the two locations, these are similar, both falling into the foreststeppe category, with chernozems rich in clay (about 30\%) and an amount of humus of about $3 \%$.

\section{Agrotechnics of the testing plots}

The two research fields (from Calarasi and Teleorman counties) benefited from an identical agrotechnics. Both were placed after the winter wheat. The incorporation of the vegetal remains was done in September 2019, at the same time with the soil preparation for autumn sowing.

In April 2020, at the germination bed preparation for the spring crops, an amount of $250 \mathrm{~kg} / \mathrm{ha}$ NPK (16:16:16) was incorporated. Fertilization was supplemented with an amount of $150 \mathrm{~kg} / \mathrm{ha}$ ammonium nitrate, applied at sowing time, together with the seed. Basic fertilization was also applied to control variants.

Subsequently, the two foliar fertilizations with biostimulators (in the stages of 3-4 and 7-8 leaves) were performed. Along with the first foliar fertilization, herbicide was applied.

\section{Biostimulators created fort the foliar fertilization}

The nine biostimulators proposed by the tanning institutes from Romania (the first seven) and Czech Republic (the last two) show the characteristics presented in detail in Table 2. All keratin and collagen hydrolysates were adjusted to a neutral $\mathrm{pH}$ (approximately 7) in order not to be harmful to the plants. 
Table 2. Presentation of biostimulators under test - main features

\begin{tabular}{|c|c|c|}
\hline No. & Biostimulator & Characteristics \\
\hline 1. & $\begin{array}{c}\text { K1 } \\
\text { (keratin hydrolysate) }\end{array}$ & $\begin{array}{l}\text { - obtained with Protamex }(1 \mathrm{~g} / \mathrm{l}) \\
\text { - dry substance }=10.60 \% ; \\
\text { - total } \mathrm{N}=12.64 \% \\
\text { - protein substance }=76.60 \% \text {. }\end{array}$ \\
\hline 2. & $\begin{array}{c}\mathbf{K 2} \\
\text { (keratin hydrolysate) }\end{array}$ & $\begin{array}{l}\text { - obtained with Esperase }(1 \mathrm{~g} / \mathrm{l}) \\
\text { - dry substance }=9.26 \% ; \\
\text { - total } \mathrm{N}=13.07 \% ; \\
\text { - protein substance }=79.20 \% \text {. }\end{array}$ \\
\hline 3. & $\begin{array}{c}\mathbf{K 3} \\
\text { (keratin hydrolysate) }\end{array}$ & $\begin{array}{l}\text { - obtained with Valkerase }(1 \mathrm{~g} / \mathrm{l}) \\
\text { - dry substance }=9.24 \% ; \\
\text { - total } \mathrm{N}=12.12 \% \\
\text { - protein substance }=73.45 \% \text {. }\end{array}$ \\
\hline 4. & $\begin{array}{c}\text { K4 } \\
\text { (keratin hydrolysate) }\end{array}$ & $\begin{array}{l}\text { - dry substance }=7.87 \% \\
\text { - total } \mathrm{N}=12.71 \% \\
\text { - protein substance }=77.02 \%\end{array}$ \\
\hline 5. & $\begin{array}{c}\text { K5 } \\
\text { (keratin hydrolysate) }\end{array}$ & $\begin{array}{l}\text { - dry substance }=7.79 \% \\
\text { - total } \mathrm{N}=12.58 \% \\
\text { - protein substance }=76.23 \%\end{array}$ \\
\hline 6. & $\begin{array}{c}\mathbf{K C} \\
\text { (keratin hydrolysate }+ \\
\text { collagen hydrolysate }+ \\
\text { macro- + microelements) } \\
\end{array}$ & $\begin{array}{l}\text { - dry substance }=14.87 \% \\
\text { - total } \mathrm{N}=8.00 \% \\
\text { - protein substance }=47.69 \%\end{array}$ \\
\hline 7. & $\begin{array}{c}\text { C } \\
\text { (collagen hydrolysate) }\end{array}$ & $\begin{array}{l}\text { - dry substance }=9.63 \% \\
\text { - total } \mathrm{N}=13.08 \% \\
\text { - protein substance }=73.51 \%\end{array}$ \\
\hline 8. & $\begin{array}{c}\text { FM1 } \\
\text { (collagen hydrolysate) }\end{array}$ & $\begin{array}{l}\text { - dry substance }=28.88 \% \\
\text { - total } \mathrm{N}=14.65 \% \\
\text { - protein substance }=88.78 \% \text {. }\end{array}$ \\
\hline 9. & $\begin{array}{c}\text { FM2 } \\
\text { (collagen hydrolysate) }\end{array}$ & $\begin{array}{l}\text { - dry substance }=29.29 \% \\
\text { - total } \mathrm{N}=14.17 \% ; \\
\text { - protein substance }=85.87 \% \text {. }\end{array}$ \\
\hline
\end{tabular}

Following the analysis of the foliar fertilizer market, aiming to obtain an efficient product, but also affordable for farmers from the economical point of view, the quantities of
2.5 and $5.0 \mathrm{l} / \mathrm{ha}$ have been projected to be tested, with dilution in 300-500 1 water.

\section{Drawing up the technological scheme}

In order to be able to draw conclusions with great accuracy, for both locations and types of experiments (microand macroplots) the use of the same technological scheme was chosen (Figure 1), only the dimensions of the plots being different. Each experimental field has been arranged in randomized blocks and three repetitions were placed.

Eventually, two experimental fields have been designed, with the following surfaces:

1) microplots (Calarasi) - 1500 sqm sown, out of which 1199 sqm were actually used, including the space of one meter between plots;

2) macroplots (Teleorman) -7 ha sown, out of which 6,36 ha were actually used, including the space of one meter between plots.

The differences between the sown areas and those actually used are represented by the protection strips on the sides of the research lots.

Performing laboratory analyses and data calculation

Harvesting was carried out very carefully, each plot at a time. For accuracy, in microplots the harvesting was done manually, and in macroplots it was mechanized, the machine being very well cleaned after each plot.

Subsequently, samples from each plot were analyzed in the laboratory, using the Infratec Foss device (Figure 2), obtaining data on moisture (\%), protein $(\%)$, hardness $(\%)$, oil content $(\%)$.

Knowing the yield per plot ( $\mathrm{kg}$ of grains) and the harvest moisture (\%), it was possible to calculate the actual yield $(\mathrm{kg} / \mathrm{ha})$. The last parameter measured was the weight of 1000 grains (WTG, g).

All data were entered in tables, and then statistically processed, by categories, focusing on yields, which most clearly highlighted the effects of foliar fertilization with the tested biostimulants. Graphs and significance were obtained by processing the data with the Anova program.

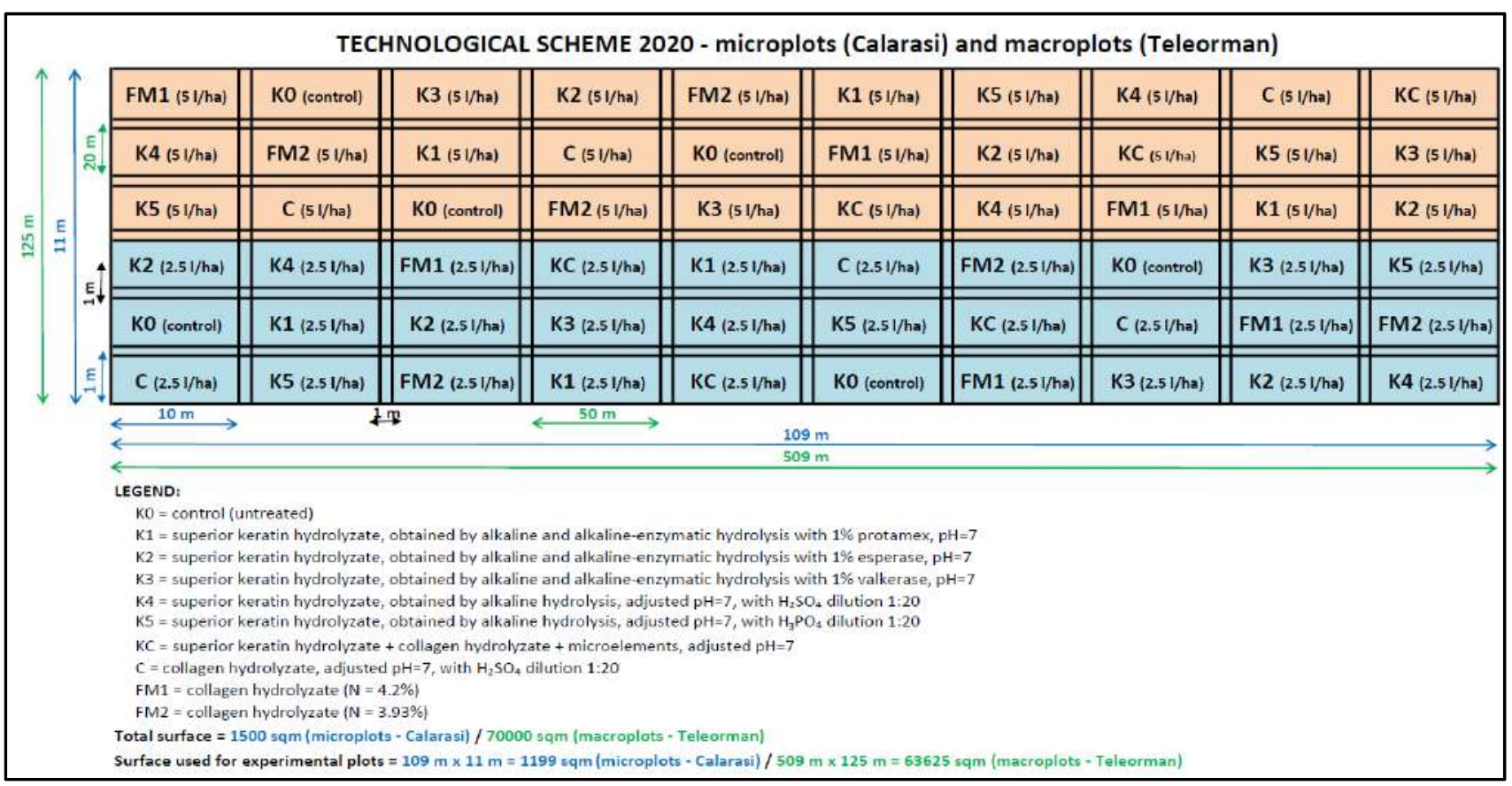

Figure 1. Technological scheme for the two research fields of maize 


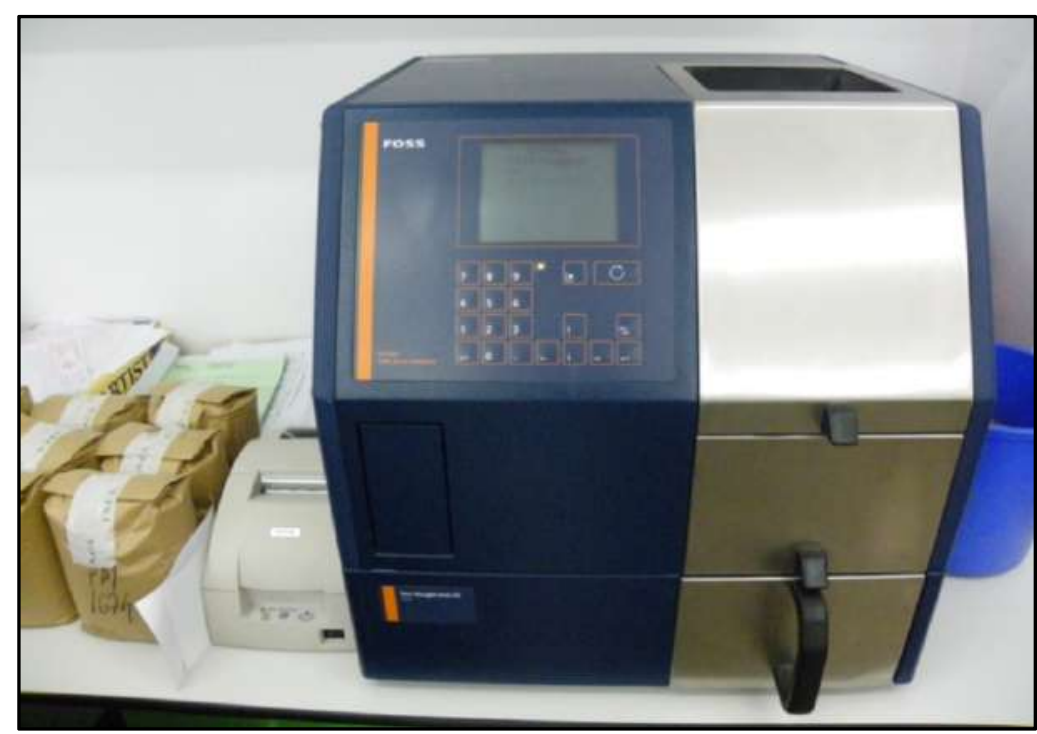

Figure 2. Infratec 1241 Grain Analyzer device, used for the qualitative analysis of maize grains

\section{Results and discussions}

A short model of data management is shown in Table 3. Subsequently, all production data from Excel were entered into the Anova statistical analysis program, resulting tables and synthesis graphs.
Since in Table 3 it can be seen that the quality parameters of the yield weren't significantly influenced by the use of biostimulators based on keratin and collagen, we focused on the yield quantity from the two experimental fields.

Table 3. Working model in managing the results obtained after the quantitative and qualitative analysis of maize yields from 2020

\begin{tabular}{|c|c|c|c|c|c|c|c|c|c|c|}
\hline No. & 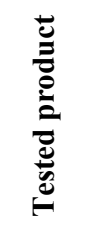 & 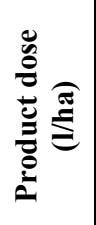 & U (\%) & 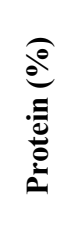 & 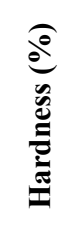 & 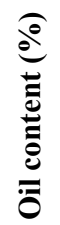 & $\begin{array}{c}\text { WTG } \\
\text { (g) }\end{array}$ & 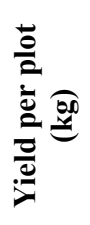 & 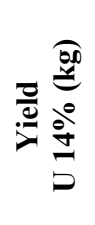 & $\begin{array}{c}\text { Yield } \\
\text { (kg/ha) }\end{array}$ \\
\hline 0 & K0 & - & 15.3 & 9.3 & 71.2 & 3.2 & 238.85 & 5.95 & 5.86 & 5860.06 \\
\hline 1 & K 1 & 2.5 & 16.2 & 9.6 & 70.4 & 3.0 & 248.55 & 5.82 & 5.67 & 5671.12 \\
\hline 2 & K 1 & 5.0 & 16.7 & 9.7 & 69.5 & 3.1 & 257.05 & 5.30 & 5.13 & 5133.60 \\
\hline 3 & K 2 & 2.5 & 16.4 & 9.7 & 70.0 & 3.0 & 233.72 & 4.80 & 4.67 & 4666.05 \\
\hline 4 & K 2 & 5.0 & 19.4 & 9.3 & 71.8 & 3.1 & 300.56 & 5.60 & 5.25 & 5248.37 \\
\hline 5 & K 3 & 2.5 & 19.4 & 9.6 & 70.2 & 3.2 & 221.6 & 5.87 & 5.50 & 5501.42 \\
\hline 6 & K 3 & 5.0 & 16.2 & 9.5 & 70.8 & 3.0 & 248.08 & 5.00 & 4.87 & 4872.09 \\
\hline 7 & K 4 & 2.5 & 15.4 & 9.5 & 71.1 & 3.4 & 409.00 & 5.99 & 5.89 & 5892.49 \\
\hline 8 & K 4 & 5.0 & 17.4 & 10.3 & 68.1 & 3.3 & 174.15 & 7.53 & 7.23 & 7232.30 \\
\hline 9 & K 5 & 2.5 & 15.7 & 9.3 & 71.2 & 3.3 & 259.86 & 6.90 & 6.76 & 6763.60 \\
\hline 10 & K 5 & 5.0 & 17.5 & 9.6 & 71.0 & 3.2 & 402.7 & 6.66 & 6.39 & 6388.95 \\
\hline 11 & $\mathrm{KC}$ & 2.5 & 19.9 & 9.4 & 71.7 & 3.1 & 305.8 & 5.77 & 5.37 & 5374.15 \\
\hline 12 & $\mathrm{KC}$ & 5.0 & 14.9 & 10.6 & 67.5 & 3.5 & 160.35 & 6.44 & 6.37 & 6372.60 \\
\hline 13 & $\mathrm{C}$ & 2.5 & 16.1 & 9.5 & 71.0 & 3.2 & 409.28 & 6.12 & 5.97 & 5970.56 \\
\hline 14 & $\mathrm{C}$ & 5.0 & 15.3 & 9.9 & 69.0 & 3.0 & 171.55 & 7.31 & 7.20 & 7199.50 \\
\hline 15 & FM 1 & 2.5 & 16.2 & 9.2 & 71.1 & 3.2 & 319.02 & 5.89 & 5.74 & 5739.33 \\
\hline 16 & FM 1 & 5.0 & 17.4 & 9.4 & 71.1 & 3.0 & 293.1 & 5.05 & 4.85 & 4850.35 \\
\hline 17 & FM 2 & 2.5 & 16.8 & 9.6 & 71.5 & 3.1 & 416.06 & 5.70 & 5.51 & 5514.42 \\
\hline 18 & FM 2 & 5.0 & 17.7 & 9.6 & 70.0 & 3.4 & 235.64 & 5.26 & 5.03 & 5033.70 \\
\hline
\end{tabular}


Table 4. Yields obtained in 2020 in microplots, on maize crop foliar fertilized with nine new biostimulators - Modelu (Calarasi)

\begin{tabular}{|c|c|c|c|c|c|c|}
\hline No. & Tested products & Dose (1/ha) & Yields (q/ha) & $\begin{array}{c}\text { Control ratio } \\
(\%)\end{array}$ & $\begin{array}{c}\text { Difference control } \\
(\mathbf{q})\end{array}$ & Sign \\
\hline 0 & Control & - & 54.57 & 100.00 & 0.00 & Control \\
\hline \multirow{2}{*}{1.} & \multirow{2}{*}{$\mathrm{K} 1$} & 2.5 & 57.03 & 104.52 & 2.47 & \\
\hline & & 5.0 & 59.80 & 109.59 & 5.23 & $* *$ \\
\hline \multirow{2}{*}{2.} & \multirow{2}{*}{ K2 } & 2.5 & 56.57 & 103.67 & 2.00 & \\
\hline & & 5.0 & 58.47 & 107.15 & 3.90 & $*$ \\
\hline \multirow{2}{*}{3.} & \multirow{2}{*}{ K3 } & 2.5 & 54.17 & 99.27 & -0.39 & \\
\hline & & 5.0 & 55.47 & 101.65 & 0.90 & \\
\hline \multirow{2}{*}{4.} & \multirow{2}{*}{ K4 } & 2.5 & 61.70 & 113.07 & 7.13 & $* * *$ \\
\hline & & 5.0 & 67.80 & 124.25 & 13.23 & $* * *$ \\
\hline \multirow{2}{*}{5.} & \multirow{2}{*}{ K5 } & 2.5 & 56.80 & 104.09 & 2.23 & \\
\hline & & 5.0 & 65.50 & 120.04 & 10.93 & $* * *$ \\
\hline \multirow[b]{2}{*}{6.} & \multirow{2}{*}{$\mathrm{KC}$} & 2.5 & 54.57 & 100.00 & 0.00 & \\
\hline & & 5.0 & 55.27 & 101.28 & 0.70 & \\
\hline \multirow{2}{*}{7.} & \multirow{2}{*}{$\mathrm{C}$} & 2.5 & 58.73 & 107.64 & 4.17 & $*$ \\
\hline & & 5.0 & 67.77 & 124.19 & 13.20 & $* * *$ \\
\hline \multirow{2}{*}{8.} & \multirow{2}{*}{ FM1 } & 2.5 & 56.90 & 104.28 & 2.33 & \\
\hline & & 5.0 & 58.13 & 106.54 & 3.57 & $*$ \\
\hline \multirow[b]{2}{*}{9.} & \multirow{2}{*}{ FM2 } & 2.5 & 57.17 & 104.76 & 2.60 & \\
\hline & & 5.0 & 58.20 & 106.66 & 3.63 & $*$ \\
\hline
\end{tabular}

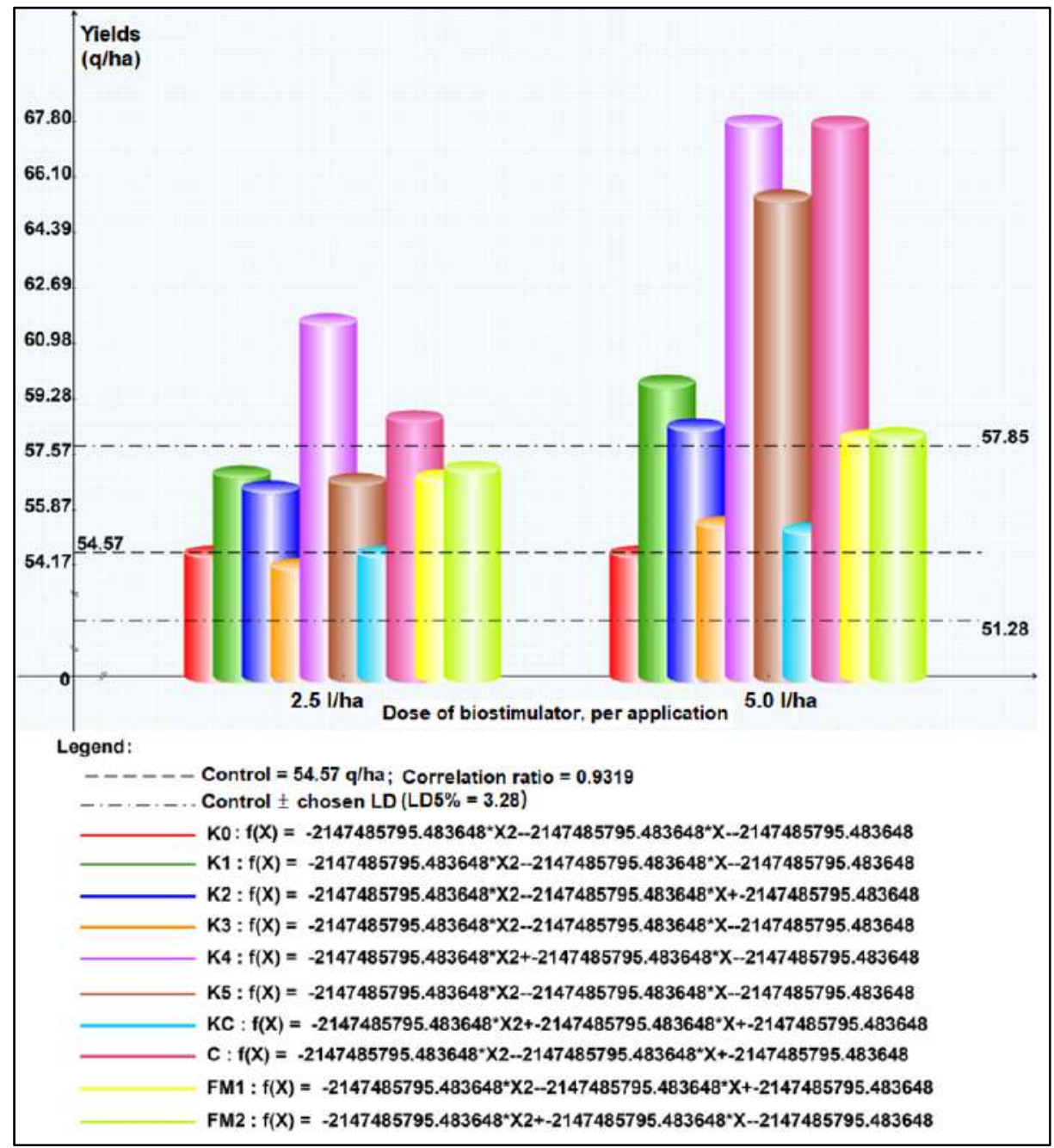

Figure 3. Graphic presentation of maize yields in microplots (Modelu) - bifactorial analysis between the tested products and the application doses 
At Modelu (Calarasi county), in microplots of $10 \mathrm{sqm}$, due to the lack of water during the critical period of development of the maize crop (in July and August the precipitations were practically non-existent), many of the surrounding crops were compromised in proportion of $100 \%$.

On not irrigated background, the experimental plots resisted, but with large yield losses. With a few exceptions, all the plots on which the new biostimulators have been tested obtained yields over the control versions (Table 4), to which the foliar treatments with biostimulators weren't applied, otherwise benefiting from the same agrotechnics.

Significant yield increases were found in products $\mathrm{K} 4$ (2.5 and $5.0 \mathrm{l} / \mathrm{ha}), \mathrm{K} 5$ (5.0 l/ha) and C (5.0 1/ha), with values between 700 and $1300 \mathrm{~kg} / \mathrm{ha}$, and distinctly significant at $\mathrm{K} 1$ (5.0 1/ha), with over $500 \mathrm{~kg} / \mathrm{ha}$ in addition.

Regarding the dose of 2.51 product/ha only the biostimulators $\mathrm{K} 4(+713 \mathrm{~kg} / \mathrm{ha})$ and $\mathrm{C}(+417 \mathrm{~kg} / \mathrm{ha})$ manage to stand out, while at the double dose only $\mathrm{K} 3$ and $\mathrm{KC}$ don't exceed the confidence interval offered by the $5 \%$ difference limit.
According to this analysis, in the plots where a dose of $5.01 \mathrm{product} / \mathrm{ha}$ has been used, there was an increase in production in each of the presented cases, with a minimum of $+70 \mathrm{~kg} / \mathrm{ha}$. The graphical representation of the above results is shown in Figure 3.

Due to the better climatic conditions of this region in 2020, the experimental field located in Calomfiresti (Teleorman county), although consisting of large plots (1000 sqm) manages to obtain clearly superior yields, compared to those in microplots (Table 5).

This is also explained by the fact that in large-scale production the pedological influence is partially limited (soil unevenness, changed composition and others). Much more conclusive and compact results can be observed in terms of large-scale productions, where the positive impact of foliar treatments with biostimulators is confirmed.

Doing another exercise and excluding the applied dose factor and analyze only the 9 products under test (Table 6), compared to the untreated foliar (control), it can be seen that almost all biostimulators offer very significant yield increases (except for the KC product) - Figure 4.

Table 5. Yields obtained in 2020 in macroplots, on maize crop foliar fertilized with nine new biostimulators Calomfiresti (Teleorman)

\begin{tabular}{|c|c|c|c|c|c|c|}
\hline No. & Tested products & Dose (l/ha) & Yields (q/ha) & Control ratio (\%) & Difference control (q) & Sign \\
\hline 1. & Control & - & 59.83 & 100.00 & 0.00 & Control \\
\hline \multirow{2}{*}{2.} & \multirow{2}{*}{ K1 } & 2.5 & 68.67 & 114.76 & 8.83 & $* * *$ \\
\hline & & 5.0 & 73.07 & 122.12 & 13.23 & $* * *$ \\
\hline \multirow{2}{*}{3.} & \multirow{2}{*}{$\mathrm{K} 2$} & 2.5 & 68.20 & 113.98 & 8.37 & $* * *$ \\
\hline & & 5.0 & 74.17 & 123.96 & 14.33 & $* * *$ \\
\hline \multirow{2}{*}{4.} & \multirow{2}{*}{ K3 } & 2.5 & 60.47 & 101.06 & 0.63 & \\
\hline & & 5.0 & 69.50 & 116.16 & 9.67 & $* * *$ \\
\hline \multirow{2}{*}{5.} & \multirow{2}{*}{ K4 } & 2.5 & 67.23 & 112.37 & 7.40 & $* * *$ \\
\hline & & 5.0 & 73.43 & 122.73 & 13.60 & $* * *$ \\
\hline \multirow{2}{*}{6.} & \multirow{2}{*}{ K5 } & 2.5 & 67.33 & 112.53 & 7.50 & $* * *$ \\
\hline & & 5.0 & 71.17 & 118.94 & 11.33 & $* * *$ \\
\hline \multirow{2}{*}{7.} & \multirow{2}{*}{$\mathrm{KC}$} & 2.5 & 59.20 & 98.94 & -0.63 & \\
\hline & & 5.0 & 61.50 & 102.79 & 1.67 & \\
\hline \multirow{2}{*}{8.} & \multirow{2}{*}{ C } & 2.5 & 69.50 & 116.16 & 9.67 & $* * *$ \\
\hline & & 5.0 & 75.20 & 125.68 & 15.37 & $* * *$ \\
\hline \multirow{2}{*}{9.} & \multirow{2}{*}{ FM1 } & 2.5 & 67.20 & 112.31 & 7.37 & $* * *$ \\
\hline & & 5.0 & 71.03 & 118.72 & 11.20 & $* * *$ \\
\hline \multirow{2}{*}{10.} & \multirow{2}{*}{ FM2 } & 2.5 & 68.03 & 113.70 & 8.20 & $* * *$ \\
\hline & & 5.0 & 69.20 & 115.65 & 9.37 & $* * *$ \\
\hline
\end{tabular}

Table 6. Unifactorial analysis of the biostimulators' influence on maize yield

\begin{tabular}{|c|c|c|c|c|c|}
\hline No. & Tested products & Yields (q/ha) & Control ratio (\%) & Difference control (q) & Sign \\
\hline 1. & Control & 59.83 & 100.00 & 0.00 & Control \\
\hline 2. & K1 & 70.87 & 118.44 & 11.03 & $* * *$ \\
\hline 3. & K2 & 71.18 & 118.97 & 11.35 & $* * *$ \\
\hline 4. & K3 & 64.98 & 108.61 & 5.15 & $* * *$ \\
\hline 5. & K4 & 70.33 & 117.55 & 10.50 & $* * *$ \\
\hline 6. & K5 & 69.25 & 115.74 & 9.42 & $* * *$ \\
\hline 7. & KC & 60.35 & 100.86 & 0.52 & \\
\hline 8. & C & 72.35 & 120.92 & 12.52 & $* * *$ \\
\hline 9. & FM1 & 69.12 & 115.52 & 9.28 & $* * *$ \\
\hline 10. & FM2 & 68.62 & 114.68 & 8.78 & $* * *$ \\
\hline
\end{tabular}




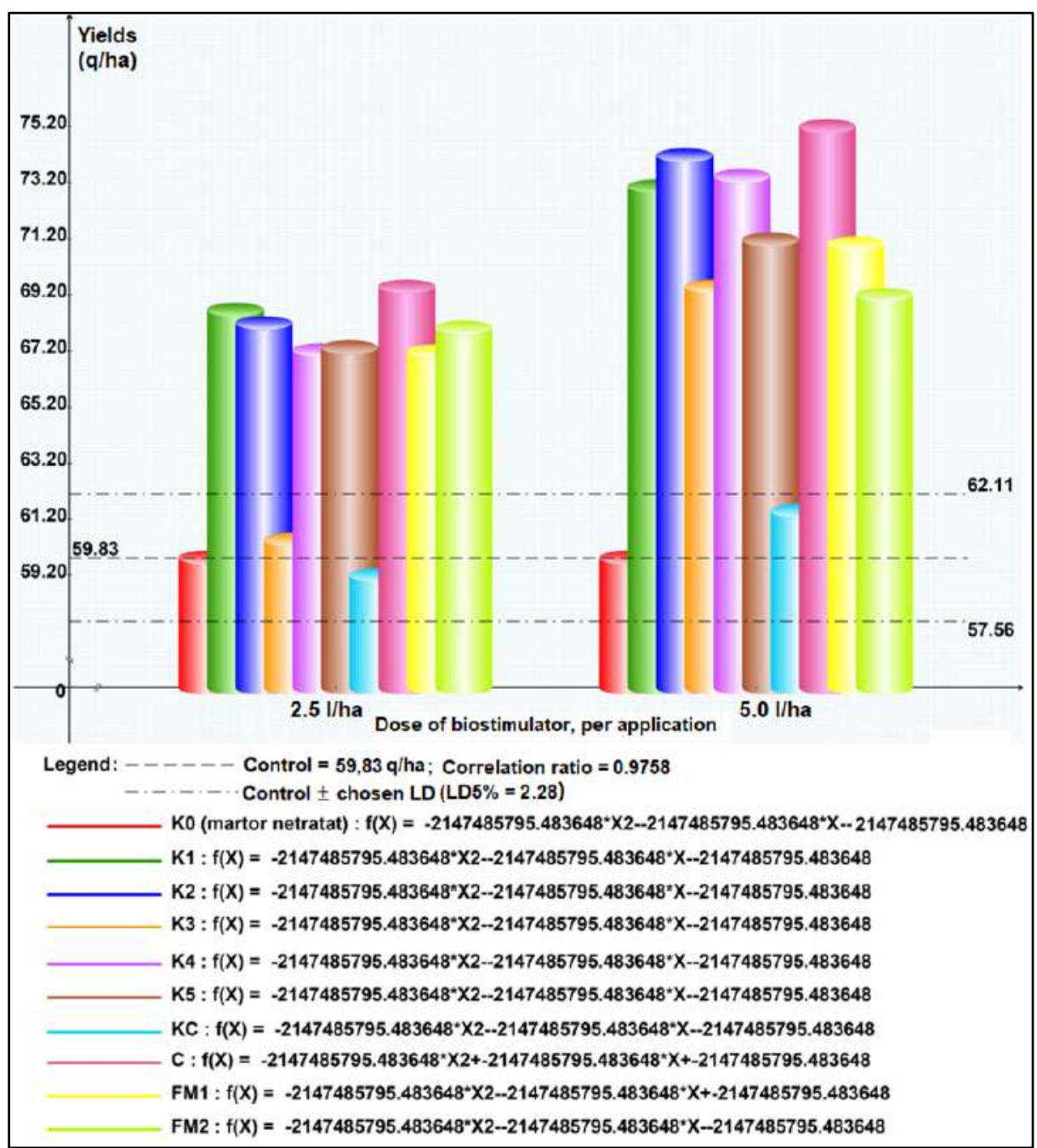

Figure 4. Graphic presentation of maize yields in macroplots (Calomfiresti) - bifactorial analysis between the tested products and the application doses

\section{Conclusion}

Quantitative and qualitative results obtained in the research fields (micro- and macroplots) were contradictory, in patches, but somehow explainable, given the abnormal climatic conditions of the agricultural year 2020. However, the effects of the nine foliar biostimulators based on keratin and collagen were significant, mainly in production, in both research locations, reaching maximum yield increases of $1537 \mathrm{~kg} / \mathrm{ha}$. The only product that wasn't confirmed is KC.

Based on these results it was concluded which of the tested biostimulators has potential, and the working plan for the second year of testing was made.

\section{Acknowledgement}

This work was supported by a grant of the Romanian Ministry of Research, Innovation and Digitalization, CCCDI - UEFISCDI, project number PN-III-P3-3.5EUK-2017-D-0098, E!12610, FERTI-MAIZE, Contract 127/2020, within PNCDI III.

\section{References}

1. LING F, SILBERBUSH M. Response of maize to foliar vs. soil application of nitrogen-phosphoruspotassium fertilizers. Journal of Plant Nutrition, 2002; 25(11): 2333-2342. DOI: 10.1081/PLN120014698

2. FERNANDEZ V, EICHERT T. Uptake of hydrophilic solutes through plant leaves: current state of knowledge and perspectives of foliar fertilization. Critical Reviews in Plant Sciences, 2009; 28(1-2): 36-68. DOI: 10.1080/07352680902743069

3. BRANKOV M, SIMIC M, DOLIJANOVIC Z, RAJKOVIC M, MANDIC V, DRAGICEVIC V. The Response of Maize Lines to Foliar Fertilizing. MDPI -Agriculture, 2020; 10(9): 365. DOI: 10.3390/agriculture 10090365

4. GIRMA K, MARTIN KL, FREEMAN KW, MOSALI J, TEAL RK, RAUN WR, MOGES SM, ARNALL DB. Determination of optimum rate and growth stage for foliar-applied phosphorus in corn. Communications 
in Soil Science and Plant Analysis, 2007; 38(9-10): 1137-1154. DOI: 10.1080/00103620701328016

5. ANDRIC L, KOVACEVIC V, KADAR I, JAMBROVIC A, PLAVSIC H, SIMIC D. Genotypic effects on boron concentrations and response on boron fertilization in maize inbred lines. Genetika, 2016; 48(1): 297-305. DOI: 10.2298/GENSR1601297A

6. BERNHARD B. Innovative foliar micronutrient sources in high-yielding corn environments. University of Illinois, Urbana-Champaign, 2016. PhD thesis. http://hdl.handle.net/2142/90631

7. ADAMEC S, ANDREJIOVA A, HEGEDUSOVA A, SEMNICER M. Evaluation of the foliar nutrition influence on selected quantitative and qualitative parameters of sugar mayze (Zea mays sk Saccharata). Potravinarstvo Slovak Journal of Food Science, 2020; 14: 208-215. DOI: 10.5219/1194

8. FERNANDEZ V, SOTIROPOULOS T, BROWN P (Ed.). Foliar fetilization: scientific principles and field practices. IFA, France, 2013; 140 pp. ISBN 979-10-92366-00-6

9. MONDA H, COZZOLINO V, VINCI G, DROSOS M, SAVY D, PICCOLO A. Molecular composition of the Humeone extracted from different green composts and their biostimulation on early growth of maize. Plant Soil, 2018; 429:407-424. DOI: 10.1007/s11104-018-3642-5

10. FRANCIS PB, EARNEST LD, BRYANT K. Maize Growth and Yield Response to a Biostimulant Amendament. Journal of Crop Improvement, 2016; 30(6): 632-640. DOI: 10.1080/15427528.2016.1207740

11. KOCIRA A, LAMORSKA J, KORNAS R, NOWOSAD N, TOMASZEWSKA M, LESZCZYNSKA D, KOZLOWICZ K, TABOR S. Changes in biochemistry and yield in response to biostimulants applied in bean (Phaseolus vulgaris L.). Agronomy $\quad$ (MDPI), 2020; 10:189. DOI: 10.3390/agronomy 10020189

12. DA SILVA RR. Comment on mRNA-sequencing analysis reveals transcriptional changes in root of maize seedlings treated with two increasing concentrations of a new biostimulant. Journal of Agricultural and Food Chemistry, 2018; 66:20612062. DOI: 10.1021 acs.jafc. 8 b00022

13. TADROS MJ, OMARI HJ, TURK MA. The morphological, physiological and biochemical responses of sweet corn to foliar application of amino acids biostimulants sprayed at three growth stages. Australian Journal of Crop Science, 2019; 13(03): 412-417. DOI: 10.21475/ajcs.19.13.03.p1335

14. BULGARI R, FRANZONI G, FERRANTE A. Biostimulants application in horticultural crops under abiotic stress conditions. Agronomy, 2019; 9:306. DOI: 10.3390/agronomy9060306

15. HU Y, BURUCS Z, SCHMIDHALTER U. Effect of foliar fertilizaton application on the growth and mineral nutrient content of maize seedlings under drought and salinity. Soil Science and Plant Nutrition, 2008; 54(1): 133-141; DOI: 10.1111/j.1747-0765.2007.00224.x

16. BROWN P, SAA S. Biostimulants in agriculture. Frontiers in Plant Science, 2015; 6:671. DOI: 10.3389/fpls.2015.00671

17. TREVISAN S, MANOLI A, QUAGGIOTTI S. A novel biostimulant, belonging to protein hydrolysates, mitigates abiotic stress effects on maize seedlings grown in hydroponics. Agronomy, 2019; 9(1):28. DOI: 10.3390/agronomy9010028

18. VAN OOSTEN MJ, PEPE O, DE PASCALE S, SILLETTI S, MAGGIO A. The role of biostimulants and bioeffectors as alleviators of abiotic stress in crop plants. Chemical and Biological Technologies in Agriculture, 2017; 4: 5. DOI: 10.1186/s40538017-0089-5

19. HOROIAS R, BECHERITU M, CIOINEAG C, BOROVINA P, GAIDAU C, NICULESCU $M$. Biometric results for maize crop, as a result of treatment with new biostimulators based on protein additives. Scientific Bulletin. Series F. Biotechnologies, 2021; XXV(1): 26-31, http://biotechnologyjournal.usamv.ro/ pdf/2021/issue 1/Art3.pdf

20. JAKAB-GABOR P, DAVID J, KOMAREK F-L. Investigation of Foliar Fertilization in Maize Production. Advanced Research in Life Science - De Gruyter, 2017; 1(1): 1-6. DOI: 10.1515/arls-20170001

21. ERTANI A, PIZZEGHELLO D, ALTISSIMO A, NARDI S. Use of meat hydrolyzate derived from tanning residues as plant biostimulant for hydroponically grown maize. Journal of Plant Nutrition and Soil Science, 2013; 176(2):287-295. DOI:10.1002/jpln.201200020

22. BECHERITU M, HOROIAS R, CIOINEAG CF, BOROVINA P. Effects of rape seeds pelleting with bioactive products based on collagen and keratin extract on germination and plantlets development. Romanian Biotechnological Letters, 2020; 25(5):1953-1960. DOI: $10.25083 / \mathrm{rbl} / 25.5 / 1953.1960$

23. BEN SEGHIR B, HEMMAMI H, SOUMEIA Z, LAOUINI SE, REBIAI A, AMOR IB, SOUICI I, BEKI A. Preparation methods keratin and nanoparticles keratin from wool: a review. Algerian Journal of Chemical Engineering, 2020; 01. DOI: 10.5281/zenodo.3930645

24. GAIDAU C, STANCA M, NICULESCU MD, ALEXE CA, BECHERITU M, HOROIAS R, CIOINEAG C, RAPA M, STANESCU IR. Wool keratin hydrolysates for bioactive additives preparation. MDPI - Materials, 2021; 14(16): 4696. DOI: $10.3390 / \mathrm{ma1} 4164696$

25. YAKHIN OI, LUBYANOV AA, YAKHIN IA, BROWN PH. Biostimulants in plant science: a global perspective. Frontiers in Plant Science, 2017; 7:2049. DOI: 10.3389/fpls.2016.02049 